\title{
Regulasi Wakaf Di Indonesia Dari Masa Orde Lama Sampai Era Reformasi Dalam Tinjauan Politik Hukum
}

\author{
Supriyadi ${ }^{1}$, Sholihul Hadi ${ }^{2}$ \\ Institut Agama Islam Negeri Kudus \\ supriyadi_rama@yahoo.co.id ${ }^{1}$, solikhul623@gmail.com²
}

\begin{abstract}
One important factor that contributed to the style and development of waqf in Indonesia was when the state participated in regulating waqf policies through a set of positive laws. In the process of formulating the policy, the vision and direction of waqf policy is largely determined by how the ruling regime sees the potential and organization of waqf, both in terms of its interests and the interests of Muslims in general. This study uses a qualitative method with a legal political approach. This study concludes that the politics of waqf law in Indonesia with a span of time from the era of independence to the era of reform. It is evident that each regulation in accordance with the era has differences according to the political conditions behind it. There are regulations that have greater political factors compared to other factors. The following are characteristics of waqf legal regulations in Indonesia, using categorization: dominant, somewhat weak and weak.
\end{abstract}

Keywords : $\quad$ Regulation, Waqf, Legal Politics

\section{Latar Belakang}

Masa awal tumbuhnya wakaf dapat ditelusuri sejak abad ke-12 M, yakni ketika terjadi penetrasi Islam oleh para guru sufi ke Nusantara. Peran guru sufi ini memberikan pengaruh pada penduduk setempat dan memberi andil bagi penyebaran Islam (Azra, 1994: 17). Sampai abad ke-14 M, pengaruh para pengembara sufi dalam mengembangkan ajaran Islam semakin luas, dan mulai masuk melalui pintu-pintu istana kerajaan di Nusantara (Ricklefs, 1994: 5). Bukti paling kuat dapat ditelusuri dari peran para Walisongo ketika memperkenalkan Islam. Untuk menyebarkan Islam ke lingkungan istana, para wali biasanya memulainya dengan mendirikan pesantren dan masjid di lingkungan kesultanan (istana). Pola ini dilakukan oleh Syekh Maulana Malik Ibrahim (w.1419) dan Sunan Ampel (w.1467), yang kemudian diikuti oleh para wali lainnya. Masjid dan pesantren-pesantren, di samping menjadi sarana penyebaran Islam, dikenal juga sebagai institusi wakaf pertama yang menjadi benih bagi perkembangan filantropi Islam pada masa berikutnya (Asrohah, 1999:146).

Dalam studinya, Rahmat Djatnika (1982: 48) menyatakan bahwa berbagai kelembagaan yang berdiri pada abad ke-15 seperti Masjid Rahmat dan Masjid Ampel belum bisa dikatakan wakaf jika dilihat dari karakteristik wakaf berdasarkan Mazhab Syafi'i. Sejauh observasi Djatnika terhadap kedua masjid tersebut, tidak ditemukan bukti ikrar wakaf dan siapa wakifnya, dua rukun wakaf yang disyaratkan Mazhab Syafi'i. Menurut Djatnika, berdasarkan catatan dan bukti-bukti historis, diketahui bahwa wakaf baru terjadi pada awal abad ke-16 M di Jawa Timur. Pada masa tersebut, terdapat enam buah wakaf dengan total 20.615 M2. Pada abad berikutnya, jumlah wakaf bertambah menjadi tujuh wakaf dan terus bertambah hingga tahun 1751-1800 menjadi 61 wakaf. Dalam perkembangan berikutnya di abad XIX, tercatat 303 lokasi wakaf tanah milik. 
Dua organisasi besar di Indonesia yaitu NU dan Muhammadiyah selama ini mengembangkan lembaga pendidikan dan sarana sosial lainnya dengan menggunakan aset wakaf. Muhammadiyah yang berdiri sejak tahun 1912, tidak saja menggalakkan wakaf masjid dan sekolah, tetapi juga mempopulerkan wakaf rumah sakit, penerbitan buku, majalah dan surat kabar. Sementara NU lebih banyak berkonsentrasi untuk mengembangkan wakaf pesantren. Sampai tahun 1978, jumlah lembaga-lembaga pesantren di Jawa dan Madura mencapai 3.195 buah (Noer, 1996: 97).

Selain wakaf NU dan Muhammadiyah di atas, yang juga menarik adalah wakaf perguruan tinggi. Dewasa ini terdapat beberapa wakaf pendidikan tinggi yang cukup berhasil dan dapat dijadikan model, di antaranya Badan Wakaf Universitas Islam Indonesia yang terdapat di Yogyakarta. Yayasan Badan Wakaf Sultan Agung Semarang juga mengelola pendidikan tinggi dan rumah sakit melalui pengembangan wakaf. Salah satu faktor yang menginspirasi pendirian wakaf perguruan tinggi ini adalah kebesaran Universitas Al-Azhar Mesir (Bamualim, 2005: 275).

Salah satu faktor penting yang ikut mewarnai corak dan perkembangan wakaf di Indonesia adalah ketika negara ikut mengatur kebijakan wakaf melalui seperangkat hukum positif. Dalam proses perumusan kebijakan tersebut, visi dan arah kebijakan wakaf banyak ditentukan oleh bagaimana rezim berkuasa melihat potensi maupun organisasi wakaf, baik dalam kerangka kepentingannya maupun kepentingan umat Islam pada umumnya (Najib, 2006: 81).

Di masa penjajahan, politik pemerintah mengenai filantropi Islam tunduk pada rasionalitas politik Islam Hindia Belanda, di mana Islam sebagai sistem nilai yang kaya akan dimensi sosial dengan berbagai preseden sejarah politiknya, dibatasi sedemikian rupa sehingga ia dipraktikkan dalam kerangka ritual-personal semata (Suminto, 1985: 120). Mengingat aktivitas filantropi Islam seringkali berhubungan antar anggota-anggota masyarakat, maka pemerintah kolonial pada akhirnya memandang perlu untuk mengatur perwakafan dengan regulasi. Sayangnya kebijakan yang dibuat tidak sepenuhnya didasarkan pada keinginan politik (political will) yang jujur serta pemahaman yang benar tentang hakikat dan tujuan filantropi Islam; akibatnya ia tidak memiliki arti penting bagi pengembangan wakaf, selain memenuhi formal administratif wakaf belaka (Najib, 2006: $82)$.

Peraturan lainnya yang berkaitan dengan hukum wakaf adalah Undang-Undang Republik Indonesia No. 7 Tahun 1989 tentang Peradilan Agama. Undang-Undang tersebut di dalam Bab III tentang Kekuasaan Pengadilan, Pasal 49 ayat (1) menyebutkan bahwa Pengadilan Agama bertugas dan berwenang memeriksa, memutus, dan menyelesaikan perkara-perkara di tingkat pertama antara orang-orang yang beragama Islam di bidang; a. Perkawinan; b. Kewarisan, wasiat, dan hibah, yang dilakukan berdasarkan hukum Islam; c. Wakaf dan sedekah (Hasanah, 2008: 20).

Proses panjang regulasi hukum Islam, utamanya hukum wakaf, sebagaimana diuraikan di atas, selalu menarik untuk diamati atau diteliti, karena kehadirannya tak lepas dari hal-hal yang melatarbelakanginya. Menurut Qodri Azizy (2004: 80) penetapan hukum Islam di dalam sebuah undang-undang ( $q \bar{a} n \bar{u} n)$ memiliki dua dimensi; bernilai Islam di satu sisi dan mempunyai kekuatan yang didukung oleh negara di sisi yanga lain. Dalam praktik, tidak jarang nuansa siyāsah syar'iyyahnya sangat menonjol, yang tidak lepas dari kepentingan politik penguasanya.

Senada dengan Azizy, menurut Mahfud MD (1999: 71) dalam kenyataan hukum itu lahir sebagai refleksi dari konfigurasi politik yang melatarbelakanginya. Dengan kata lain, 
kalimat-kalimat yang ada di dalam aturan hukum itu tidak lain merupakan kristalisasi dari kehendak-kehendak politik yang saling bersaingan. Satjipto Rahardjo (1985: 71) mengemukakan bahwa kalau kita melihat hubungan antara subsistem politik dan subsistem hukum, tampak bahwa politik memiliki konsentrasi energi yang lebih besar sehingga hukum berada pada posisi yang lemah.

Penelitian ini berupaya untuk meneliti regulasi wakaf di Indonesia dari latar belakang politik hukum, dimulai setelah kemerdekaan Indonesia sampai era Reformasi dengan keluarnya UU No. 41 Tahun 2004 tentang Wakaf dan PP. No. 42 Tahun 2006 tentang Pelaksanaan UU No. 41 Tahun 2004 tentang Wakaf. Berdasarkan latar belakang masalah di atas, maka research problem (rumusan masalah) dalam penelitian ini adalah bagaimana terjadinya proses politik hukum atas lahirnya regulasi wakaf di Indonesia; setelah kemerdekaan sampai era Reformasi (keluarnya UU No. 41 Tahun 2004 tentang Wakaf dan PP. No. 42 Tahun 2006 tentang Pelaksanaan UU No. 41 Tahun 2004 tentang Wakaf)?

\section{Teori dan Metode}

\subsection{Kajian Teori}

\subsubsection{Regulasi Hukum Wakaf dalam Lintasan Sejarah Indonesia}

Peraturan-peraturan tentang hukum wakaf yang dibuat oleh pemerintah Kolonial Belanda pada zaman kemerdekaan masih tetap diberlakukan selama belum ada regulasi wakaf yang baru. Karena permasalahan perwakafan merupakan bagian dari hukum pertanahan (agraria) maka pemerintah memberikan perhatian khusus tentang perwakafan di dalam UU No. 5 Tahun 1960 tentang Peraturan Dasar Pokok-Pokok Agraria (UUPA). Pada Pasal 49 ayat (3) UUPA disebutkan; perwakafan tanah milik dilindungi dan diatur dengan Peraturan Pemerintah (Hasanah, 2008: 12).

UUPA 1960 lahir sebagai bagian dari propaganda politik Demokrasi Terpimpin dan sekaligus upaya melegitimasi kebijakan politik itu. Demokrasi Terpimpin dituangkan dalam konsep-konsep politik ala Orde Lama, yaitu; Revolusi Nasional, Manifesto Politik dan faham Sosialisme Indonesia.

Konsep-konsep politik tersebut dituangkan di dalam konsideran UUPA; "Menimbang", pada huruf (b) bahwa hukum agraria yang masih berlaku sekarang ini sebagian tersusun berdasarkan tujuan dan sendi-sendi dari pemerintahan jajahan dan sebagian dipengaruhi olehnya, hingga bertentangan dengan kepentingan rakyat dan negara di dalam menyelesaikan "Revolusi Nasional" sekarang ini serta pembangunan semesta; "Berpendapat", pada huruf (d) bahwa hukum agraria tersebut harus pula merupakan pelaksanaan dari pada Dekrit Presiden tanggal 5 Juli 1959, ketentuan dalam pasal 33 Undang-Undang Dasar dan "Manifesto Politik" Republik Indonesia, sebagai yang ditegaskan dalam Pidato Presiden tanggal 17 Agustus 1960, yang mewajibkan negara untuk mengatur pemilikan tanah dan "memimpin" penggunaannya, hingga tanah di seluruh wilayah kedaulatan bangsa dipergunakan untuk sebesar-besar kemakmuran rakyat, baik secara perseorangan maupun secara gotong-royong; "Mengingat"; (a) Dekrit Presiden tanggal 5 Juli 1959; (b) Pasal 33 Undang-Undang Dasar; (c) Penetapan Presiden No. 1 tahun 1960 (L.N. 1960-10) tentang Penetapan Manifesto Politik Republik Indonesia tanggal 17 Agustus 1959 sebagai Garis-Garis Besar Haluan Negara, dan Amanat Presiden tanggal 17 Agustus 1960; (d) Pasal 5 jo. 20 Undang-Undang Dasar; dengan persetujuan Dewan Perwakilan Rakyat Gotong Royong (Harsono, 2002: 4). 
Penjelasan UUPA, yang diatur dalam Tambahan Lembaran Negara (TLN) Nomor 2044, juga memuat konsep-konsep politik Demokrasi Terpimpin, sebagaimana yang tercantum di dalam Penjelasan Umum poin 1; (a) karena hukum agraria yang berlaku sekarang ini sebagian tersusun berdasarkan tujuan dan sendi-sendi dari pemerintah jajahan, dan sebagiannya lagi dipengaruhi olehnya, hingga bertentangan dengan kepentingan rakyat dan negara di dalam melaksanakan pembangunan semesta dalam rangka menyelesaikan "Revolusi Nasional" sekarang ini; (b) karena sebagai akibat dari politik-hukum pemerintah jajahan itu hukum agraria tersebut mempunyai sifat dualisme, yaitu dengan berlakunya peraturan-peraturan dari dan yang didasarkan atas hukum Barat, hal mana selain menimbulkan pelbagai masalah antar-golongan yang serba sulit, juga tidak sesuai dengan cita-cita persatuan bangsa; (c) karena bagi rakyat asli hukum agraria penjajahan tidak menjamin kepastian hukum (Santoso, 2012: 346347).

Faham "Sosialisme Indonesia" secara jelas menjadi landasan lahirnya UU No. 5 Tahun 1960 tentang Peraturan Dasar Pokok-Pokok Agraria. Hal ini dapat dilihat pada Penjelasan UUPA (TLN 2043) romawi III angka (1); ...hukum agraria sekarang ini mempunyai sifat "dualisme" dan mengadakan perbedaan antara hak-hak tanah menurut hukum adat dan hak-hak tanah menurut hukum Barat, yang terpokok pada ketentuanketentuan dalam Buku II Kitab Undang-Undang Hukum Perdata Indonesia. UndangUndang Pokok Agraria bermaksud menghilangkan dualisme itu dan secara dasar hendak mengadakan kesatuan hukum, sesuai dengan keinginan rakyat sebagai bangsa yang satu dan sesuai pula dengan kepentingan perekonomian (Harsono, 2002: 36).

Dengan sendirinya hukum agraria baru itu, harus sesuai dengan kesadaran hukum daripada rakyat banyak. Oleh karena rakyat Indonesia sebagian besar tunduk pada hukum adat, maka hukum agraria yang baru tersebut akan didasarkan pula pada ketentuan-ketentuan hukum adat itu, sebagai hukum yang asli, yang disempurnakan dan disesuaikan dengan kepentingan masyarakat dalam negara yang modern dan dalam hubungannya dengan dunia internasional, serta disesuaikan dengan "Sosialisme Indonesia". Sebagaimana dimaklumi maka hukum adat dalam pertumbuhannya tidak terlepas pula dari pengaruh politik dan masyarakat kolonial yang kapitalistis dan masyarakat swapraja feodal (Harsono: 2002; 37-38).

Dengan sistem politik hukum yang demikian itu maka berimbas pada pengaturan wakaf yang disebutkan dalam Undang- Undang Nomor 5 Tahun 1960 tentang Peraturan Dasar Pokok-Pokok Agraria. Pada Pasal 49 ayat (3) menetapkan; Perwakafan tanah milik dilindungi dan diatur dengan Peraturan Pemerintah. Namun, pada kenyataannya Peraturan Pemerintah yang mengatur tentang perwakafan tanah milik baru dapat terlaksana tujuhbelas tahun kemudian, yaitu PP No. 28 Tahun 1977 tentang Perwakafan Tanah Milik, setelah terjadinya pergantian konfigurasi politik era Orde Lama ke era Orde Baru.

\subsubsection{Regulasi Hukum Wakaf Orde Baru}

Selain PP No. 28 Tahun 1977 tentang Perwakafan Tanah Milik, Regulasi wakaf pada era Orde Baru juga diatur dalam UU No. 7 Tahun 1989 tentang Peradilan Agama, dalam Bab III tentang Kekuasaan Pengadilan Pasal 49 (1) menyebutkan bahwa Pengadilan Agama bertugas dan berwenang memeriksa, memutus dan menyelesaikan perkara-perkara di tingkat pertama antara orang-orang yang beragama Islam di bidang; (1) perkawinan; (b) kewarisan, wasiat, dan hibah, yang dilakukan berdasarkan hukum Islam; (c) wakaf dan sedekah (Hasanah, 2008: 20). 
Regulasi selanjutnya yang mengatur tentang wakaf pada masa Orde Baru adalah Kompilasi Hukum Islam berdasarkan Inpres No.1 Tahun 1991. Pada Bab III KHI itu mengatur hukum perwakafan, yang terdiri dari lima bab dan limabelas pasal. (Hasanah, 2008: 22).

Dalam tinjauan politik hukum, PP No. 28 Tahun 1977 tentang Perwakafan Tanah Milik dilatarbelakangi atas dua hal; (1) tertib administrasi perwakafan; dan (2) proteksi terhadap gerakan komunisme. Hal ini tercermin dari Penjelasan atas Peraturan Pemerintah Nomor 28 Tahun 1977 tentang Perwakafan Tanah Milik yang dikeluarkan oleh Menteri Dalam Negeri, Amirmachmud, pada tanggal 26 November 1977. Pada penjelasan umum disebutkan; di lain pihak banyak terdapat persengketaanpersengketaan tanah disebabkan tidak jelas status tanahnya, sehingga apabila tidak segera diadakan pengaturan, maka tidak saja akan mengurangi kesadaran beragama dari mereka yang menganut ajaran Islam, bahkan lebih jauh akan menghambat usaha-usaha pemerintah untuk menggalakkan semangat dan bimbingan "kewajiban ke arah beragama" (menjauhi faham dan gerakan komunisme), sebagaimana terkandung dalam ajaran Pancasila digariskan dalam Ketetapan Majelis Permusyawaratan Rakyat Nomor IV/MPR/1973 (Harsono, 2002: 127).

Upaya politis pemerintah untuk melakukan tertib administrasi dalam rangka menjaga stabilitas nasional, juga secara eksplisit disebutkan di dalam konsideran PP No. 28 Tahun 1977. Ada tiga hal yang secara administratif menjadi alasan lahirnya PP No. 28 Tahun 1977; (a) pada waktu yang lampau, pengaturan tentang perwakafan tanah selain dari belum memenuhi kebutuhan, juga belum diatur secara tuntas dalam suatu peraturan perundang-undangan, sehingga memudahkan terjadinya penyimpangan dari hakikat dan tujuan wakaf itu sendiri. Ini disebabkan karena beraneka ragamnya bentuk wakaf (wakaf keluarga dan wakaf umum) dan tidak adanya keharusan mendaftarkan benda-benda yang diwakafkan itu. Akibatnya, banyak benda-benda yang diwakafkan tidak diketahui lagi keadaannya, bahkan ada di antaranya yang telah menjadi milik ahli waris pengurus (nadzir) wakaf bersangkutan. Hal ini akan menimbulkan; (b) keresahan di kalangan umat Islam yang menjurus kepada perasaan antipati terhadap wakaf; dan (c) dalam masyarakat banyak terjadi persengketaan mengenai tanah wakaf karena tidak jelas status tanah wakaf yang bersangkutan (Daud Ali, 1988: 99-100).

Pemerintahan Orde Baru menetapkan ekonomi sebagai sentral di bidang pembangunan, maka stabilitas nasional menjadi syarat mutlak bagi terwujudnya tujuan itu. Sebab, tanpa stabilitas nasional yang mantap terutama di bidang politik, labilitaslabilitas dalam masyarakat dan kegoncangan-kegoncangan ekonomi dapat menghambat pembangunan secara keseluruhan. Dalam kondisi seperti itu, kepastian dan ketertiban melalui hukum sangat dibutuhkan (Moeljarto, 1987: 68).

Sebagai tindak lanjut dari upaya mewujudkan tertib hukum di bidang wakaf guna menjaga stabilitas nasional, maka pemerintah mengeluarkan beberapa peraturan yang mendukung PP No. 28 Tahun 1977 tentang Perwakafan Tanah Milik.

Untuk menciptakan tertib hukum dan administrasi, perwakafan tanah milik yang diatur di dalam PP No. 28 Tahun 1977 ditangani oleh dua departemen secara terpadu yaitu Departemen Agama dan Departemen Dalam Negeri, sesuai kewenangan masingmasing. Peraturan dua Departemen Implementasi terpadu antar dua departemen itu sesuai dengan isi UU No. 28 Tahun 1977, yang mengatur pembagian tugas perwakafan tanah milik; Departemen Agama bertugas pada ikrar wakaf dan pembuatan akta ikrar wakaf serta menerima laporan setelah mendapatkan pencatatan dan sertifikat, sedangkan 
Departemen Dalam Negeri bertugas mencatat dan menerbitkan sertifikat wakaf, sebagaimana dijelaskan pada Pasal 9 dan 10 PP No. 28 Tahun 1977 (Harsono, 2002: 122).

Kekhawatiran pemerintah akan terjadinya ketidaktertiban dalam perwakafan cukup realistis, karena faktanya banyak terjadi perselisihan disebabkan kurangnya bukti-bukti otentik yang diperlukan. Bahkan ada di antara masyarakat yang merahasiakan pewakaf yang sebenarnya, karena beranggapan wakaf adalah bagian dari bentu sedekah yang lebih utama jika dirahasiakan.

Contoh tanah wakaf yang menjadi persengketaan terjadi pada sebuah masjid di Jatibarang, Brebes. Satu keluarga tetangga masjid itu tiba-tiba mengaku bahwa sebagian tanah miliknya menjadi milik masjid tersebut. Tanah dimaksud yang luasnya hanya empat meter persegi dipermasalahkan dan melibatkan berbagai instansi. Si ibu yang merasa menjadi pemilik tanah tersebut tidak rela dan akan meminta kembali tanah yang sudah lama masuk dalam pagar masjid (Moh Amir, 2000: 28).

Contoh lain permasalahan tanah wakaf terjadi pada wakaf Masjid Kauman Kutowinangun Kebumen. Masjid Kauman Kutowinangun ini yang kemudian diberi nama Masjid "Taqwa", menurut saksi hidup, dapat ditelusuri kisahnya mulai tahun 1959. Tanah masjid tersebut merupakan tanah wakaf yang diwakafkan oleh keluarga Arumbinang (gelar kehormatan Bupati Kebumen di masa lalu). Kapan tepat waktu dan siapa nama wakifnya pada saat akad tidak ada dokumen yang mencatatnya (Kholid, 2012: 21). Namun menurut Aspan, saksi hidup yang menjadi kebayan desa sejak tahun 1961, masyarakat sudah mafhum bahwa tanah tersebut adalah tanah wakaf keluarga Arumbinang. Menurutnya, pada tahun 1959 bangunan yang ada baru terdiri dari sebuah masjid, tempat wudlu berupa dua buah padasan besar serta kulah dengan konstruksi berupa bejana berhubungan. Sedangkan di sebelah selatan masjid banyak terdapat pohon pisang dan kelapa gading. Di halaman masjid yang luas ketika itu, terdapat beberapa petak sawah milik masjid dan sebuah bangunan tempat tinggal pengasuh masjid yakni Kiai Dahlan. Sepeninggal Kiai Dahlan, Kiai Mas'ad yang menjadi penerusnya tidak menempati rumah tersebut karena rumah wakaf itu telah beralih fungsi menjadi Sekolah Rakyat Perempuan (SRP) (Kholid, 2012: 21).

Pada tahun 1960, Kepala Desa Kutowinangun waktu itu, Lurah Soepardi yang dikenal kurang amanah itu mengundang Mantri Klangsir dan timnya dari Magelang. Lurah Soepardi minta agar tanah wakaf itu, terutama yang terdapat bangunan rumah wakaf diukur. Tidak lama kemudian setelah pengukuran itu, tanpa izin umat Islam, bangunan itu dibongkar, lalu di atasnya dibangun Sekolah Teknik Negeri (STN). Selanjutnya, entah bagaimana prosesnya dibangun pula Kantor Urusan Agama (KUA) Kutowinangun, yang tadinya terletak di desa Rejosari. Sekolah tersebut pada masa jabatan Wedana Sutrisno telah berubah menjadi SMP Negeri Kutowinangun (Kholid, 2012: 22).

Pada tahun 1980, ada Peraturan Pemerintah yang menyatakan bahwa tanah-tanah yang tidak diurus oleh keluarganya dalam jangka waktu tertentu akan menjadi tanah pemerintah (dinasionalisasikan). Umat Islam setempat pada waktu itu juga tidak menyangka bahwa tanah wakaf tersebut ikut dinasionalisasikan. Dengan demikian, akhirnya tanah wakaf tersebut menjadi milik pemerintah, sehingga bangunan Masid At Taqwa dianggap menumpang pada tanah milik pemerintah. Setelah tanah wakaf berubah menjadi milik pemerintah, dan rumah wakaf menjadi SMP N, maka di atas 
tanah wakaf tersebut kemudian didirikan kantor Koramil, kolam dan kompleks pertokoan (Kholid, 2012: 24).

Di samping alasan di atas, aksi-aksi yang dilakukan oleh PKI cukup mengkhawatirkan Pemerintahan Orde Baru. Selama ini PKI melakukan klaim sepihak terhadap UUPA 1960 dan melakukan sabotase-sabotase terhadap tanah wakaf (Wiradi, 2000: 141).

Contoh manuver yang dilakukan oleh PKI terhadap benda wakaf, tergambar dalam penelitian Agus Fathuddin Yusuf tentang wakaf Masjid Agung Semarang. Pada awalnya dasar hukum wakaf Masjid Besar Semarang adalah Stb. 1912 No. 605 jo. Besluit Gubernur Jenderal Hindia Belanda tanggal 12 Agustus 1896 Nomor 43. Untuk mengamankan tanah-tanah tersebut pada tahun 1962 Menteri Agama (KH. Saefuddin Zuhri) menguatkan dan menegaskan berdasarkan Keputusan Menteri Agama Nomor 92 Tahun 1962 bahwa tanah-tanah tersebut adalah tanah wakaf yang pengelolaannya diserahkan kepada BKM Kodya Semarang. Alasannya, hampir semua tanah tersebut pada saat itu diserobot dan dikuasai oleh PKI (BTI). Setelah terjadinya G. 30 S/PKI yang membuat posisi PKI hancur maka segera diadakan persidangan untuk menentukan status yang sebenarnya atas tanah-tanah wakaf Masjid Besar Semarang. Melalui proses persidangan yang panjang, lebih dari 60 kali persidangan, akhirnya tanah-tanah wakaf tersebut bisa kembali sesuai dengan yuridis formal kepada Pengurus Masjid Besar Semarang (Moh Amir, 2000: 14).

Tak pelak bahwa cara-cara PKI itu telah menimbulkan konflik di mana-mana. Dan tidak sedikit tanah-tanah wakaf yang menjadi korban. Dalil mereka adalah bahwa semua yang ada termasuk tanah adalah comunal bezit atau milik bersama (Yusuf, 2000: 26).

Dalam sejarahnya, PKI senantiasa menggunakan tanah sebagai bagian dari sarana politiknya. Para pemuda pasca revolusi yang tidak puas, marah dan benci, cepat sekali bereaksi terhadap pemimpin manapun yang menyebabkan ketidaksenangan mereka dan siapa saja yang menawari para pemuda itu tempat untuk menumpahkan perlawanan mereka terhadap status quo. Awal keberhasilan PKI dalam segmen masyarakat petani berasal dari kondisi-kondisi yang sama, yaitu meluasnya ketidakpuasan dan keresahan masyarakat terhadap kehidupan. Meskipun agak mengabaikan "kebijakan tanah" dan masalah-masalah petani selama beberapa tahun (dalam sejarahnya, PKI baru mengadakan Konferensi Pertanahan Nasional pada bulan April 1959), PKI tetap mendapat dukungan luas melalui kemenangan slogan-slogannya yang memikat dan heboh, di antaranya; "tanah untuk rakyat" dan "tanah untuk petani” (Mintz, 2002: 199-200).

Dari instruksi bersama diinstruksikan kepada Kepala Kantor Wilayah Departeme Agama Propinsi, Kepala Kantor Wilayah Badan Pertanahan Nasional Propinsi, Kepala Kantor Departemen Agam Kabupaten/Kotamadya dan Kepala Kantor Pertanahan Kabupaten/Kotamadya seluruh Indonesia, mengenai; pertama, untu mengadakan koordinasi sebaik-baiknya dalam penyelesaian sertifikat tanah wakaf. Kedua, mengupayakan penyelesaian sertifikat tanah wakaf tersebut selambat-lambatnya pada akhir Pelita V. Ketiga, menggunakan tolok ukur satuan biaya Proyek Operasi Nasional Pertanahan (PRONA) sebagai dasar pembiayaan penyelesaian sertifikat tanah wakaf. Keempat, merencanakan penyerahan secara masal sertifikat tanah dalam rangkaian acara hari ulang tahun Undang-Undang Pokok Agraria ke-31 tanggal 24 September 1991 dan Hari Amal Bhakti Departemen Agama ke-46 tanggal 3 Januari 1992 yang penyerahannya akan dilakukan oleh Menteri Agama RI dan Kepala Badan Pertanahan Nasional. Kelima, mengintensifkan tanah wakaf baik yang bersumber APBN, APBD, maupun dari 
masyarakat. Keenam, melaporkan kepada Gubernur Kepala Daerah Tingkat I, Kepala Badan Pertanahan dan Menteri Agama RI apabila dalam sertifikat tanah wakaf tersebut mengalami kesulitan/hambatan tentang pembiayaan, tenaga teknis, peralatan dan kebutuhan lainnya. Ketujuh, Instruksi ini supaya dilaksanakan sebagaimana mestinya dan setiap tiga bulan melaporkan perkembangannya kepada Gubernur Kepala Daerah Tingkat I, Kepala Badan Pertanahan Nasional dan Menteri Agama RI. Kedelapan, Instruksi ini mulai berlaku sejak dikeluarkan tanggal 30 Nopember 1990 (Hasanah, 2008: 21).

Dalam tinjauan politik hukum, Kompilasi Hukum Islam bertujuan untuk kebutuhan teknis yustisial, yaitu kebutuhan perangkat hukum materiil bagi instansi pemerintah yang membutuhkan, dan sebagai tindak lanjut dari UU No. 14 Tahun 1970 tentang KetentuanKetentuan Pokok Kekuasaan Kehakiman yang memposisikan Peradilan Agama sejajar dengan Peradilan-Peradilan lainnya. Hal ini tercermin dari konsideran KHI maupun penjelasannya. Dalam konsideran KHI huruf (b) disebutkan; bahwa Kompilasi Hukum Islam tersebut oleh Instansi Pemerintah dan oleh masyarakat yang memerlukannya dapat dipergunakan sebagai pedoman dalam menyelesaikan masalah-masalah di bidang tersebut (Ditjenbinbaga Islam, 2000: 1).

Menteri Agama, sebagai Pembantu Presiden, dalam Surat Keputusannya Nomor: 154 Tahun 1991 tanggal 22 Juli 1991, dalam rangka melaksanakan Instruksi Presiden tersebut, meminta kepada seluruh Instansi Departemen Agama, dan instansi pemerintah lainnya yang terkait agar menyebarluaskan KHI dimaksud. Dalam bagian kedua diktum Keputusan Menteri Agama tentang Pelaksanaan Instruksi Presiden itu disebutkan pula bahwa seluruh lingkungan instansi itu agar menerapkan KHI tersebut di samping Peraturan Perundangundangan lainnya dalam menyelesaikan masalah-masalah di bidang hukum perkawinan, kewarisan dan perwakafan (Hasanah, 2008: 22).

Lahirnya Kompilasi Hukum Islam tidak terlepas pula dari politik kepentingan akomodasi rezim Orde Baru yang berikutnya (setelah UU No.7 Tahun 1989 tentang Peradilan Agama), terhadap politik Islam. Bahkan Munawir Sjadzali (1988) selaku Menteri Agama, dalam proses-proses politik yang berlangsung, sering mengatakan bahwa penggagas KHI adalah Presiden Soeharto sendiri. Memang tidak jelas, siapa yang sesungguhnya menjadi penggagas KHI, ada yang menyebut Busthanul Arifin (Ditbinbapera Depag RI, 1992: 132, Arifin, 2001: 171), Ibrahim Husain (Tim Penyusun Biografi, 1990: 224), dan Munawir Sjadzali (Abdurrahman, 1992: 31). Ismail Sunny tidak mengatakan Presiden Soeharto adalah penggagas KHI, tetapi dia mengatakan bahwa Soeharto adalah orang yang mendorong terbitnya SKB antara Menteri Agama dan Ketua Mahkamah Agung tentang KHI itu (Gunaryo, 2006: 234).

Busthanul menduga bahwa penempelan nama Seoharto pada KHI oleh Munawir di atas memang disengaja, karena itu memiliki arti penting dilihat dari konstelasi politik pada saat itu di mana Presiden memegang kendali kekuasaan yang luar biasa. Dengan penempelan itu, diharapkan bahwa perjalanan KHI itu beserta seluruh upaya legitimasinya dapat berlangsung dengan lancar. Apalagi menurut Busthanul, saat itu terlihat adanya indikasi penentangan yang datang dari Gedung Sekretariat Negara yang di dalamnya ada Sudharmono dan Murdiono, serta A. Hamid S. Attamimi (Wakil Sekretaris Kabinet). Di balik layar ketiga orang inilah yang menurut Busthanul menentang KHI (Gunaryo, 2006: 234).

Busthanul sendiri merasa ditinggalkan dengan sengaja ketika suatu saat dilakukan rapat untuk membahas KHI tanpa mengundang dia sebagai Ketua Tim Penyusun KHI maupun sebagai pejabat Mahkamah Agung yang paling bertanggungjawab terhadap 
penyelesaian kompilasi itu. Padahal rapat tersebut sangat menentukan bentuk keberlakuan dan kekuatan KHI, apakah itu berbentuk Peraturan Pemerintah, Instruksi, atau lainnya. Inisiatif rapat datang dari Sekretariat Negara. Rapat itu dipimpin oleh Tamimi. Sedang yang diundang dari Tim Penyusun KHI adalah Muhtar Zarkasyi (Direktur Pembinaan Badan Peradilan Agama) dan Maesuri. Rapat memutuskan bahwa dasar keberlakuan KHI adalah Instruksi Presiden (Gunaryo, 2006: 234-235).

Mahkamah Agung RI bersama dengan Departemen Agama RI memprakarsai adanya Proyek Pembangunan Hukum Islam melalui yurisprudensi, suatu proyek yang akan bertanggung jawab atas pembentukan Kompilasi Hukum Islam. Dengan demikian, pemebentukan KHI dilaksanakan oleh sebuah Tim Pelaksana Proyek yang ditunjuk dengan SKB Ketua MA dan Menag RI, No. 07/KMA/1985 dan No. 25 Tahun 1985, pada tanggal 25 Maret $1985^{1}$ (Siroj, 2012: 274).

Pembentukan tim ini seperti tersebut di dalam konsideran SKB tersebut, didasarkan pada fungsi pengaturan MA RI terhadap jalannya peradilan di semua lingkungan peradilan di Indonesia, khususnya terhadap Peradilan Agama. Penjabaran dari fungsi itu salah satunya adalah mengadakan Kompilasi Hukum Islam yang selama ini menjadi hukum materiil di Pengadilan Agama. Selain itu didasarkan juga pada UU No. 13 Tahun 1965 dan UU No. 14 Tahun 1970. Atas dasar hal tersebut, SKB menunjuk dan mengangkat para pejabat MA dan Depag RI sebagai pelaksana proyek tersebut (Wahid dan Rumadi, 2001: 150).

Berdasarkan susunan pelaksana proyek seperti termaktub dalam SKB, tampak bahwa, penempatan personil didasarkan pada jabatan struktural yang bertanggung jawab terhadap pembinaan Peradilan Agama, dengan menggunakan asas perimbangan (equilibrium) dari dua instansi pemrakarsa, yakni keseimbangan personil di Depag dan MA RI. Dari enambelas personil yang menduduki jabatan sebanyak limabelas orang; delapan personil dari MA RI dan tujuh personil dari Depag RI, sisanya dari MUI, yakni KH. Ibrahim Husain, LML (Harahap, 1990: 94-95).

Selain para birokrat dari Depag dan Hakim Agung dari MA RI yang turut terlibat dalam proses penyusunan KHI adalah para ulama, dan para cendekiawan/intelektual muslim. Kedua pihak yang disebut terakhir masuk dalam lingkaran proses penyusunan, karena memang dilibatkan oleh Tim Pelaksana Proyek. Dari sini, maka intensitas keterlibatan mereka dalam proses pembentukan KHI mempunyai nilai yang berbeda-beda. Peran dan fungsi dalam pengambilan keputusan juga berlainan.

\subsection{Metode Penelitian}

Studi ini menggunakan metode kualitatif dengan pendekatan politik hukum. Metode kualitatif digunakan untuk mendapatkan data berbentuk kata verbal, bukan angka (Muhadjir, 1996: 29). Pendekatan politik hukum digunakan untuk menganalisis regulasi hukum wakaf sebagai produk politik pemerintah dengan data sekunder.

Teknik pengumpulan data dalam studi ini ada dua yaitu; dokumenter, dan kepustakaan. Dokumen dibedakan antara yang pribadi dengan yang formal. Dokumen pribadi mencakup; buku harian, surat pribadi, dan otobiografi. Sedangkan formal mencakup; foto, arsip negara, data statistik dan produk budaya materiil (Muhadjir, 1996: 103).

\footnotetext{
${ }^{1}$ Ketua MA RI saat itu adalah Ali Said, S.H. dan Menteri Agama RI adalah H. Munawir Sjadzali, M.A.
} 


\section{Hasil dan Pembahasan}

UU No. 41 Tahun 2004 tentang Wakaf dan PP No 42 Tahun 2006 tentang Pelaksanaan UU No. 41 Tahun 2004) dalam Tinjauan Politik Hukum. Dalam tinjauan politik hukum, UU No. 41 Tahun 2004 tentang Wakaf merupakan langkah politis pemerintah dalam mensukseskan PROPENAS (Program Pembangunan Nasional) di bidang pembangunan hukum.

Hal itu terlihat dari surat yang diajukan oleh Direktorat Pengembangan Zakat dan Wakaf cq. Menteri Agama kepada Menteri Kehakiman dan Hak Asasi Manusia perihal izin prakarsa RUU Perwakafan. Dalam surat tersebut dimuat perlunya penyempurnaan peraturan perundang-undangan tentang wakaf selama ini setelah mempertimbangkan halhal sebagai berikut: ${ }^{2}$

Pertama, dalam Undang-Undang Nomor 25 Tahun 2000 tentang Program Pembangunan Nasional (PROPENAS) 2000-2004, disebutkan bahwa salah satu indikator keberhasilan pembangunan nasional disektor hukum adalah ditetapkannya undang-undang tentang Hukum Terapan Peradilan Agama, yaitu salah satunya tentang Undang-Undang Wakaf.

Kedua, ketentuan mengenai perwakafan yang selama ini berlaku, belum dapat dijadikan landasan yang cukup kuat untuk menyelesaikan persoalan-persoalan perwakafan, tak terkecuali pemberdayaannya dalam sektor ekonomi. Regulasi-regulasi tersebut adalah UU No. 5 Tahun 1960 tentang Peraturan Dasar Pokok-Pokok Agraria, Pasal 14 ayat (1) huruf b dan Pasal 49 ayat (3), PP No. 28 Tahun 1977 tentang Perwakafan Tanah Milik, Inpres No.1 Tahun 1991 yang memuat KHI yang sebagian materinya berkaitan dengan wakaf, dan beberapa peraturan lain termasuk Instruksi Bersama Menteri Dalam Negeri dan Menteri Agama, dan beberapa peraturan yang bersifat teknis yang dikeluarkan oleh Menteri Agama.

Bersamaan dengan surat izin prakarsa penyusunan RUU Wakaf yang ditujukan kepada Menteri Kehakiman dan HAM tersebut disertakan Konsepsi Pengaturan tentang Perwakafan sebagai landasan awal upaya penyusunan RUU Wakaf. Konsepesi Pengaturan tentang Perwakafan tersebut dapat dijaba

Pertama, kebijakan di bidang hukum (legal development policy) dalam Garis-Garis Besar Haluan Negara Tahun 1999-2004, TAP MPR No. IV/MPR/1999, yang diwarnai oleh tekad bangsa indonesia untuk melakukan reformasi di segala bidang kehidupan, dirumuskan sebagai bagian integral (integral part) dari seluruh kebijakan sosial (social policy) yang pada dasarnya merupakan usaha sistematis dari seluruh bangsa untuk meningkatkan kesejahteraan seluruh warganya di berbagai bidang kehidupan.

Kedua, substansi perwakafan memiliki karakteristik yang berbeda dengan sektor pemerintah (public sector) dan sektor swasta (private sector), sehingga memerlukan pengaturan tersendiri. Apalagi dalam menghadapi era pasar bebas mutlak diperlukan perangkat peraturan perundang-undangan yang memiliki visi masa depan, tetapi tetap berpijak pada prinsip kedaulatan nasional.

\footnotetext{
2 Surat Menteri Agama kepada Menteri Kehakiman dan HAM beserta lampirannya, Nomor: MA/451/2002, Perihal: Izin Prakarsa RUU Wakaf, tertanggal 27 Desember 2002.
} 
Ketiga, di antara tujuan RUU Wakaf adalah; menjamin kepastian hukum di bidang wakaf serta sebagai koridor kebijakan publik dalam rangka advokasi dan penyelesaian kasus-kasus wakaf. Terciptanya tertib hukum dan tertib aturan di bidang wakaf dalam wadah Negara Kesatuan Republik Indonesia merupakan sasaran RUU Wakaf.

Politik hukum pemerintah dalam regulasi wakaf di atas, sebagaimana diatur dalam Undang-Undang Nomor 25 Tahun 2000 tentang Program Pembangunan Nasional (PROPENAS) 2000-2004, yang menyebutkan bahwa salah satu indikator keberhasilan pembangunan nasional di sektor hukum adalah ditetapkannya undang-undang tentang Hukum Terapan Peradilan Agama, yaitu salah satunya tentang Undang-Undang Wakaf, mendapatkan respon yang beragam dari para ulama, pakar, ormas Islam dan fraksi-fraksi di DPR.

Pada saat diadakan pertemuan ulama, pakar/tokoh, dan ormas Islam dengan Departemen Agama, maka para pakar dan ulama serta ormas Islam memberikan pandangannya seputar kebijakan politik hukum pemerintah dalam regulasi hukum wakaf. ${ }^{3}$

KH. Syukri Zarkasyi (Gontor) menyatakan, dalam penyusunan UU Wakaf kelak, jangan sampai memposisikan pemerintah sebagai penguasa yang serba mengatur. Sedangkan Muhammadiyah memberikan pandangannya, posisi pemerintah seharusnya lebih bersifat koordinatif dalam kaitannya dengan Badan Wakaf Indonesia yang dibentuk dan dikembangkan oleh masyarakat. Senada dengan Muhammadiyah, Persis (Persatuan Islam) mengisyaratkan organisasi pengelola wakaf atau Badan Wakaf Nasional dibuat oleh masyarakat dan dikukuhkan oleh pemerintah. Fungsi dari pemerintah adalah mengawasi dan melindungi dengan menjalankan UU agar dapat mengamankan bendabenda wakaf yang disengketakan.

Majelis Ulama Indonesia (MUI) dalam Rapat Dengar Pendapat Umum (RDPU) dengan Komisi VI DPR menyatakan; MUI menyambut dengan gembira terhadap inisiatif pemerintah yang mengajukan RUU tentang Wakaf kepada DPR. MUI berharap agar UU tentang Wakaf kelak bisa dijadikan sandaran dan payung hukum yang dapat menstimulasi perwakafan di tanah air. Namun dalam kesempatan kali ini MUI memberikan penekanan agar UU ini tidak sekedar berhenti pada aspek normatif dan tidak dijalankan optimal sebagaimana mestinya. Dalam kesempatan itu Pengurus Besar Nahdlatul Ulama (PBNU) juga menyambut gembira dan menyampaikan terima kasih kepada semua pihak yang terkait dengan pembahasan RUU tentang Wakaf, karena PBNU melihat bahwa peraturan perundang-undangan tentang pengaturan dan pengelolaan wakaf memerlukan penyempurnaan, meskipun relatif agak terlambat. ${ }^{4}$

Pada saat Rapat Dengar Pendapat Umum (RDPU) antara Komisi VI DPR RI dengan BAZNAS dan LAZNAS ada beberapa masukan dari lembaga-lembaga itu mengenai kebijakan politik pemerintah dalam regulasi hukum wakaf. LAZ Pos Keadilan Peduli Umat (PKPU) menyatakan; dalam klausul pengadministrasian harta wakaf yang melibatkan pemerintah, khususnya KUA sebagai Pejabat Pembuat Akta Ikrar Wakaf (PPAIW), agar dihilangkan. Karena keterlibatan pihak pemerintah akan menambah rumitnya birokrasi wakaf yang tidak perlu. Dengan demikian peran nadzir wakaf harus

\footnotetext{
${ }^{3}$ Pertemuan Ulama, Pakar/Tokoh dan Ormas Islam tentang RUU Wakaf, tanggal 6 Maret 2003, dibuka oleh Menteri Agama, tempat Operation Room Departemen Agama. = Time New Roman

${ }^{4}$ Laporan hasil Pertemuan Ulama, Pakar/Tokoh dan Ormas Islam tentang RUU Wakaf tanggal 6 Maret 2003.
} 
lebih ditingkatkan sehingga pengelolaan wakaf murni ditangani oleh pihak masyarakat (swasta). ${ }^{5}$

Untuk mensinkronkan antara pemerintah dan DPR RI serta memenuhi ketentuan Pasal 123 Keputusan DPR RI No. 03A/DPR RI/2001, diadakan Rapat Kerja. Dalam Rapat Kerja itu banyak tanggapan dari fraksi-fraksi yang ada di Komisi VI DPR RI mengenai kebijakan politik regulasi hukum wakaf yang diajukan pemerintah kepada DPR. ${ }^{6}$

\section{Simpulan}

Studi ini telah berusaha mempelajari politik hukum wakaf di Indonesia dengan rentang waktu mulai era kemerdekaan sampai era reformasi.Terbukti bahwa masingmasing regulasi sesuai dengan eranya memiliki perbedaan sesuai kondisi politik yang melatarbelakanginya. Terdapat regulasi yang memang faktor politiknya lebih besar dibanding dengan faktor yang lainnya. Berikut ini adalah karakteristik regulasi hukum wakaf di Indonesia, dengan menggunakan kategorisasi: dominan, agak lemah dan lemah.

\footnotetext{
5 Risalah DPR RI, 31 Agustus 2004: Rapat Dengar Pendapat Umum (RDPU) tentang RUU Wakaf dengan BAZNAZ/LAZNAZ, hari Selasa 31 Agustus 2004, tempat Ruang Sidang Komisi VI DPR RI.

6 Risalah DPR RI: Rapat Kerja antara Panja Komisi VI DPR RI dengan Pemerintah, hari Senin tanggal 6 September 2004, tempat Ruang Sidang Komisi VI DPR R!
} 


\section{DAFTAR PUSTAKA}

Abdullah, Abdul Rahman Haji, 1990, Pemikiran Umat Islam di Nusantara, Sejarah dan Perkembangannya hingga Abad ke- 19, Kuala Lumpur: Dewan Bahasa dan Pustaka.

Abdulgani, Ruslan, 1973, Nasionalism, Revolution and Guided Democracy, Melbourne: Monash University.

Abdurrahman, 1979, Masalah Perwakafan Tanah Milik dan Kedudukan Tanah Wakaf di Negara Kita, Bandung: Alumni.

Pressindo.

1992, Kompilasi Hukum Islam di Indonesia, Jakarta: Akademiko

Abdillah, Masykuri, "The Status of Islamic Law in Indonesia under The New Order Government," Makalah disampaikan pada Workshop on Islamic Revivalism and State Response: The Experience of Malaysia, Indonesia and Brunai, Singapore, 2-3 Juni 1997.

Abdurrahman, Abul Farj, tt, Al Syarh Al Kabīr 'alā Matan al Mughnī, Jilid 6, Mesir: Maktabah al Sunnah al Muhammadiyah.

Abubakar, Irfan, 2005, "Pelembagaan Wakaf di Pesantren Tebuireng Jombang", dalam Chaider S. Bamualim dan Irfan Abibakar (ed.), Revitalisasi Filantropi Islam: Studi Kasus Lembaga Zakat dan Wakaf di Indonesia, Jakarta: Pusat Bahasa dan Budaya UIN Jakarta.

Abu Zahrah, Muhammad, 1971, Muhādlarāt fì al waqfi, Kairo: Dar al Fikr al ‘Arabi.

Abu Su'ud, Muhammad, tt, Risālatu fì al Jawāzi Waqfi al Nuqūd, Bairut: Dar Ibn Hazm.

Abu al-Su'ud, Sayyid Ali, tt, Al Wilāyah 'alā al Waqfi, Mesir: Al Azhar. al- Abijy, Adijani, 1989, Perwakafan Tanah di Indonesia, Jakarta: Rajawali. Alfian, 1978, Pemikiran dan Pembaharuan Politik Indonesia, Jakarta: Gramaedia.

Ali, Muhammad Daud, 1997: Hukum Islam dan Peradilan Agama, Jakarta, Rajawali Press.

Alisjahbana, Sutan Takdir, 1966, Indonesia: Social and Cultural Revolution, terj. Benedict R. Anderson, Kuala Lumpur: Oxford University Press.

Amal, Ichlasul, 1992, Regional and Central Government in Indonesia Politics, West Sumatra and South Sulawesi 1949-1979, Yogyakarta: Gadjah Mada University Press.

Amin, Muhammad, tt, Hāsyiyah Ibnu 'ābidīn (Rad al Mukhtār 'alā Dur al Mukhtār, Mesir: Al Utsmaniyah.

Anshari, Endang S., 1981, Piagam Jakarta 22 Juni 1945, Jakarta: Rajawali Press. Anwar, Syafi'i, M., 1995, Pemikiran dan Aksi Islam Indonesia: Sebuah Kajian Politik tentang Cendikiawan Muslim Orde Baru, Jakarta: Paramadina. 
Arifin, Busthanul, 2001, Transformasi Hukum Islam ke Hukum Nasional; Bertenun dengan Benang-Benang Kusut, Jakarta: Yayasan Al-Hikmah. Jakarta: P3M.

Arjoso, Amin (ed.), 2001, Pancasila Dasar Falsfah Negara, Jakarta: Yayasan Kepada Bangsaku.

al-Asqalanai, Ahmad bin Hajar, 1319 H, Fath al Bārī Syarh al Bukhārī, Mesir: Al Khairiyah.

Asrohah, Hanun, 1999, Sejarah Pendidikan Islam, Jakarta: Logos.

al-Auzjundi, Fakhruddin, 1310 H, Al Fatāwā al Khāniyah, Jilid 3, Mesir: Al amiriyah.

Azhary, Tahir, M., 2004, Kumpulan Hasil Seminar Perwakafan, Jakarta: Direktorat Pengembangan Zakat dan Wakaf Depag RI.

Azizy, Qodri A., 2004, Hukum Nasional: Eklektisisme Hukum Islam dan Hukum Umum, Jakarta Selatan: Teraju.

, 2002, Eklektisisme Hukum Nasional: Kompetisi antara Hukum Islam dan Hukum umum, Yogyakarta: Gama Media.

Azra, Azyumardi, 1994, Jaringan Ulama Timur Tengah dan Kepulauan Nusantara Abad XVII dan XVIII, Bandung: Mizan.

, 1989, "Islam di Asia Tenggara, Pengantar Pemikiran”, dalam Azra (ed), Perspektif Islam Asia Tenggara, Jakarta: YOI.

Modernisasi, Jakarta: Logos.

Bamualim, Chaider S., "Badan Wakaf Universitas Islam Indonesia: Wakaf untuk Modernisasi Perguruan Tinggi Islam" dalam Chaider S. Bamualim dan Irfan Abu Bakar (ed.), 2005, Reaktualisasi Filantropi Islam: Studi Kasus Lembaga Zakat dan Wakaf di Indonesia, Jakarta: Pusat Bahasa dan Budaya UIN Jakarta dan the Ford Foundation.

Barron, J.B., 1922, Mohammedan Wakfs in Palestine, Jerusalem: Greek Convent Press.

Basyir, Ahmad Azhar, 1986, Hukum Islam tentang Wakaf, Ijarah dan Syirkah, Bandung: Al- Ma'arif.

al- Baijuri, tt, Hāsyiyah al Baijūrū, Juz II, Bairut: Dar al Fikr.

Benda, Harry J., 1981, Bulan Sabit dan Matahari Terbit, Jakarta: Pustaka Jaya.

Bisri, Cik Hasan, 2004, Pilar-Pilar Penelitian Hukum Islam dan Pranata Sosial, Jakarta: Raja Grafindo Persada.

1998, Peradilan Agama di Indonesia, Jakarta: Raja Grafindo Persada.

al-Bishri, Hilal, 1355 H, Waqfu Hilāl, Mesir: Majlis Dairah al Ma'arif al Utsmaniyah.

Blitanagy, Josef Johanes, 1984, Hukum Agraria Nasional Suatu Pembaruan Sejarah dan Sistem Politik Hukum Pertanahan, Jakarta: Nusa Indah.

Bruinessen, Martin Van, 1999, Kitab Kuning: Pesantren dan Tarekat, Bandung: Mizan.

al-Bukhari, Abu Abdillah, tt, Matn al Bukhari, Mesir, An Nashriyyah.

Bulkin, Farchan, "Negara, Masyarakat dan Ekonomi” dalam Prisma No. 8 Tahun 1984.

Candra, Tri, "Warisan Kolonial yang Belum Diselesaikan: Nasionalisasi Perusahaan di Jember", Makalah disampaikan dalam Workshop on the Economic Side of Decolonisation di Yogyakarta, pada tanggal 18-19 Agustus 2004. 
ad-Daruquthni, Ali, 1310 H, Sunan al Dāruquthnī, India: Delhi Press.

Daud Ali, Mohammad, 1988, Sistem Ekonomi Islam, Zakat dan Wakaf, Jakarta: UI Press.

Depag RI, 2004, Undang-Undang Republik Indonesia Nomor 41 Tahun 2004 tentang Wakaf, Jakarta: Dirjen Bimas Islam dan Urusan Haji.

, 2007a, Paradigma Baru Wakaf di Indonesia, Jakarta: Direktorat Pemberdayaan

Wakaf Dirjen Bimas Islam.

-----------,2007b, Strategi Pengembangan Wakaf Tunai di Indonesia, Jakarta: Direktorat Pemberdayaan Wakaf Dirjen Bimas Islam.

Islam.

-----------, 2007d, Panduan Pemberdayaan Tanah Wakaf Produktif Strategis di Indonesia, Jakarta: Direktorat Pemberdayaan Wakaf Dirjen Bimas Islam.

2007e, Pedoman Pengelolaan Wakaf Tunai, Jakarta: Direktorat Pemberdayaan

Wakaf Dirjen Bimas Islam.

Dumper, Michael, 1994, Wakaf Kaum Muslim di Negara Yahudi, Jakarta: Penerbit Lentera. Ditjen Bimas Islam Depag RI, 2007, Fiqh Wakaf, Jakarta: Departemen Agama RI.

2004 tentang Wakaf, Jakarta: Departemen Agama RI.

Ditjen Binbaga Islam Depag RI, 1986, Ilmu Fiqh, Jakarta: Departemen Agama RI.

Departemen Agama RI.

Ditbinbapera, 1992, Kompilasi Hukum Islam di Indonesia, Jakarta: Departemen Agama RI. Djatnika, Rahmat, 1982, Wakaf Tanah, Surabaya: Al-Ikhlas.

, 1983, Pandangan Islam tentang Infaq Shadaqah, Zakat dan Wakaf sebagai Komponen dalam Pembangunan, Surabaya: Al- Ikhlas.

Djunaidi, Achmad, dan Thobieb Al-Asyhar, 2007, Menuju Era Wakaf Produktif, Jakarta: Mumtaz Publishing.

Drewes, G.W.J. 1989. "Pemahaman Baru tentang Kedatangan Islam di Indonesia", dalam Ahmad Ibrahim, Sharon Shiddique dan Yasmin Husain, Readings on Islam Shoutheast Asia, alih bahasa A. Setiawan Abadi. Jakarta: LP3ES.

Effendi, Deden, 2010, "Legislasi, Implementasi dan Kontribusi Hukum Perwakafan dalam Pembangunan Keagamaan dan Kesejahteraan di Indonesia" disertasi, Bandung: UIN Sunan Gunung Djati.

Emmerson, D.K., 1974, The Bureaucracy in Indonesia, Cambridge: Centre for International Studies MIT.

Fathurrahman, Tata, 2007, "Wakaf dan Kemiskinan; Perspektif Hukum Islam dan UU No. 41 Tahun 2004 tentang Wakaf," disertasi, Jakarta: IAIN Syarif Hidayatullah.

Feith, Herbert, 1962, The Decline of Constitusional Democracy in Indonesia, Ithaca: Cornell University Press.

Fiderspiel, Howard M., 1996, Persatuan Islam, Pembaharuan Islam Indonesia Abad XX, Yogyakarta: Gadjah Mada University Press.

Fuad, Mahsun, 2005, Hukum Islam di Indonesia: dari Nalar Partisipatoris hingga Emansipatoris, Yogyakarta: LKiS.

Fuady, Munir, 1999, Hukum Bisnis dalam Teori dan Praktik, Bandung: Citra Aditya Bakti.

Gaffar, Afan, tt, "Parties and Party Systems in Indonesia, Since Constitusional Democratic Era." tidak diterbitkan. 
1992, Javanese Voters, A Case Study of Election Under Hegemonic Party System, Yogyakarta: Gadjah Mada University Press.

Gazalba, Sidi, 1989, Mesjid Pusat Ibadah dan Kebudayaan, Jakarta: Pustaka al- Husna.

Geertz, Clifford, 1981, Abangan, Santri dan Priyayi dalam Masyarakat Jawa, Jakarta: Pustaka Jaya.

al-Ghamrawi, Muhammad Zuhri, tt, Al Sirāj al Wahhāb 'alā al matn al Minhāj, Mesir: Musthafa Bab al Halabi

Gibb, H.A.R., dan H. Bowen, 1957, Islamic Society and the West, London: Oxford University Press.

Gibb, H.A.R., 1993, Aliran-Aliran Modern dalam Islam, terj. Machnun Husein, Jakarta: Raja Grafindo Persada.

Gofar, Abdul, 2004, Kumpulan Hasil Seminar Perwakafan Depag RI,Jakarta: Direktorat Pengembangan Zakat dan Wakaf.

Gunaryo, Ahmad, 2006, Pergumulan Politik dan Hukum Islam; Reposisi Peradilan Agama dari Peradilan "Pupuk Bawang" Menuju Peradilan yang Sesungguhnya, Yogyakarta: Pustaka Pelajar.

al- Haitami, Ibnu Hajar, tt, Tuhfatul Muhtāj fì Syarhil Minhāj, Bairut: Dar al Fikr.

Halim, Abdul, 2005, Politik hukum Islam di Indonesia, Jakarta: Ciputat Press.

, 2000, Peradilan Agama dalam Politik Hukum Islam Indonesia, Jakarta: Raja Grafindo Persada.

Harahap, Yahya, 1990, Kedudukan Kewenangan dan Acara Peradilan Agama UU No. 7 Tahun 1989, Jakarta: Pustaka Kartini.

, 1988, “Tujuan KHI,”dalam IAIN Syarif Hidayatullah, Kajian Islam tentang Berbagai Masalah Kontemporer, Jakarta: Hikmat Syahid Indah.

---------------, 2003, Kedudukan Kewenangan dan Acara Peradilan Agama UU No. 7 Tahun 1989, Edisi II, Jakarta: Sinar Grafika.

Harsono, Boedi, 2002, Hukum Agraria Indonesia, Jakarta: Djambatan.

Hartono, Sunaryati, "Pembinaan Hukum Nasional pada Pembangunan Jangka Panjang Tahap Kedua dalam Konteks Hukum Islam,"dalam Mimbar Hukum, No. 8 IV Tahun 1993, Jakarta: Al Hikmah.

Hasanah, Uswatun, "Wakaf dalam Peraturan Perundang-undangan di Indonesia" dalam Jurnal Wakaf dan Ekonomi Islam Al-Awqaf BWI (ISSN 2085-0824), Volume 1 Nomor 01 Desember 2008.

Hatta, Mohammad, 2005, Hukum Tanah Nasional dalam Perspektif Negara Kesatuan, Yogyakarta: Media Abadi.

Hazairin, 1974, Tujuh Serangkai Tentang Hukum, Jakarta: Tintamas.

Hilmi, Hasbullah, 2012, Dinamika Pengelolaan Uang Wakaf (Studi tentang Perilaku Pengelolaan Wakaf Uang Pasca Pemberlakuan UU No. 41 Tahun 2004), Disertasi Pasca Sarjana IAIN Walisongo Semarang.

Huijbers, Theo, 1982, Filsafat Hukum dalam Lintasan Sejarah, Yogyakarta: Kanisius. Hurgronje, Snouck C., 1996, Aceh: Rakyat dan Adat Istiadatnya, Jakarta: INIS.

1992, Nasihat-nasihat C. Snouck hurgronje Semasa Kepegawaiannya kepada Pemerintah Hindia Belanda 1889-1936, Jilid VII, Jakarta: INIS.

Ibnu Miftah, Abul Hasan, 1340 H, Al Muntazi' al Mukhtārr, Mesir: Al Ma’arif. 
Ibnu Qudamah, Abu Muhammad, 1328 H, Al Mughnī 'alā al Mukhtashar al Khurāfì̀, 1348 H, Mesir: Al Manar.

Ibrahim, Abu Ishak, tt, Al Muhadzab, Jilid I, Mesir: Isa al Babi al Halabi.

Ibrahim Bik, Ahmad, 1363 H/1944 M, Al Waqfu Wa Bayānu Ahkāmihi, Mesir: Maktabah Wahbah.

Ichtijanto SA, 1990, Hukum Islam dan Hukum Nasional, Jakarta: Ind-Hill-Co.

Imam, Sutiknjo, 1990, Politik Hukum Agraria Nasional, Yogyakarta: BP UGM.

Jay, Robert, 1957, Santri dan Abangan, Religious Schism in Rural Java, Harvard: Harvard University.

Jokosutomo, 1955, Sejarah Politik Hukum Adat, Jakarta: TP Press.

al-Kabisi, Muhammad Abid, 2004, Hukum Wakaf, terj. Ahrul Sani, Jakarta: IIMaN Press.

Kaiseipo, Manuel, "Dari Kepolitikan Birokratik ke Korporatisme Negara; Birokrasi dan Politik di Indonesia Era Orde Baru," dalam Jurnal Ilmu Politik AIPI-LIPI 1987.

Kanumoyoso, Bondan, 2001, Nasionalisasi Perudahaan Belanda di Indonesia, Jakarta: Sinar Harapan.

Kholid, Mas'ad, 2012, "Problem Sekitar Harta Wakaf" dalam Agus Fathuddin Yusuf, Melacak Banda Masjid yang Hilang, Semarang: Aneka Ilmu.

Khosyiah, Siah, 2010, Wakaf dan Hibah: Perspektif Ulama Fikih dan Perkembangannya di Indonesia, Bandung: Pustaka Setia.

al-Khurasyi, Abu Abdullah, 1317 H, Syarh al Khurāsȳ̄ 'alā Mukhtashar Khalīl, Mesir: Al Amiriyah.

King, Dwigt Y., 1979, "Indonesia New Order as a Bureaucratic Polity, a Neopatrimonial Regime or a Bureaucratic Aothorita-Rian Regime What Difference Does it Make?" makalah untuk pertemuan tahunan The Association of Asian Studies, Los Angeles.

Laboratorium Ilmu Politik (LIP) FISIP UI, 1998, Mengubur Sistem Politik Orde Baru, Jakarta: Mizan Pustaka

Lapidus, Ira, M., 2000, Sejarah Sosial Umat Islam, Jakarta: Raja Grafindo Persada.

Lubis, Mulya T., 1987, Hak Asasi Manusia dan Pembangunan, Jakarta: YLBHI.

Lubis, Ridwan M., 1992, Sejarah Islam Indonesia, Medan: IAIN Press.

Mackie, Jamie, "Problem of Indonesian Inflasion" dalam Tri Candra Warisan Kolonial yang Belum Diselesaikan: Nasionalisasi Perusahaan di Jember, Makalah disampaikan dalam Workshop on the Economic Side of Decolonisation di Yogyakarta, pada tanggal 18-19 Agustus 2004.

Mahfud MD, Moh., 2004, Pergulatan Politik dan Hukum di Indonesia, Yogyakarta: Gama Media.

, 1999, Hukum dan Pilar-Pilar Demokrasi, Yogyakarta: Gama Media. , 2010, Politik Hukum di Indonesia, Jakarta: PT Rajagrafindo Persada.

al Marghinani, Burhanuddin, 1356 H, Al Hidayah, Mesir: Musthafa Muhammad.

Mas'oed, Mohtar, 1989, Ekonomi dan Struktur Politik Orde Baru, Jakarta: LP3ES.

Masyhuri, Aziz, 1997, Masalah Keagamaan: Hasil Muktamar dan Munas Alim Ulama Nahdlatul Ulama Ke-1 sampai dengan ke-26, Surabaya: Dinamika Press.

al-Mawardi, 1994, Al Hāwī al Kabīr, Bairut: Dar al Fikr.

Meoljarto T., 1968, Beberapa Pokok Pikiran tentang Sistem Kepartaian di Indonesia, Yogyakarta: Seksi Penerbitan Fakultas Sospol UGM.

1987, Politik Pembangunan: Sebuah Analisis Konsep, Arah dan Strategi, Yogyakarta: Bayu Indah Grafika. 
Mintz, Jeanne S., Muhammad, Marx, Marahaen: Akar Sosialisme Indonesia, Yogyakarta: Pustaka Pelajar.

Moh Amir, Saliyun, 2012, "Lika-Liku Mengamankan Tanah Wakaf," dalam Agus Fathuddin Yusuf, Melacak Banda Masjid yang Hilang, Semarang: Aneka Ilmu.

Mortimer, Rex, 1989, Indonesian Communism Under Sukarno: Ideology and Politics, Ithaca: Cornell University Press.

Mudzhar, Atho, M., 1998, Pendekatan Studi Islam dalam Teori dan Praktek, Yogyakarta: Pustaka Pelajar.

Muhadjir, Noeng, 1996, Metode Penelitian Kualitatif, Yogyakarta: Raka Sarasin.

Muhaimin, Yahya, 1990, Bisnis dan Politik: Kebijaksanaan Ekonomi Indonesia1950-1980, terj. Hasan Basari dan Muhadi Sugiono, Jakarta: LP3ES.

Muslim, Imam Al Qusyairi, tt, Shahīh Muslim, Bandung, Syirkah Ma'arif

an-Na'im, Abdullah Ahmed, 1997, Toward an Islamic Reformation Civil Liberties, Human Right and Internatonal Law, terj. Ahmad Suaedy dan Amiruddin Arrani, Yogyakarta: LKiS.

Najib, Tuti A. Dan Ridwan al-Makassary (ed.), 2006, Wakaf, Tuhan dan Agenda Kemanusiaan, Jakarta: Centre for the Study and Culture (CSRC) UIN Jakarta.

an-Nasa 'i, Abu Abdurrahman, tt, Sunan An Nasā’i ma`a Hāsyiyah As Sanadi, Mesir: Al Mathba'ah.

an-Nawawi, Abu Zakaria, tt, Raudhat at Thālibīn, Mesir: Maktab al Islami li al Thaba'ah Wa an Nasyr.

Noer, Deliar, 1996, Gerakan Modern Islam di Indonesia 1990-1942, Jakarta: LP3ES.

Nonet, Philippe dan Philip Selznick, 1978, Law and Society in Transition: Toward Responsive Law, New York: Harper and Row.

Notonagoro, 1984, Politik Hukum dan Pembangunan Agraria, Jakarta: Bina Aksara.

Nusantara, Abdul Hakim G, 1988, Politik Hukum Indonesia, Jakarta: LP3ES.

Noorhadi, Saifuddin, 2005, "Wakaf dalam Perspektif Hukum Agraria Nasional," disertasi, Surabaya: IAIN Sunan Ampel.

Pardoyo, 1993, Sekularisasi dalam Polemik, Jakarta: Pustaka Utama Grafiti.

Parlindungan, A.P., 1981, Kapita Selecta Hukum Agraria, Bandung: Alumni.

Pelzer, Karl J., 1991, Sengketa Agraria: Pengusaha Perkebunan Melawan Petani, Jakarta: Pustaka Harapan.

Poerwadarminta, 2003, Kamus Umum Bahasa Indonesia, Jakarta: Balai Pustaka.

Praja, Juhaya S., 1997, Perwakafan di Indonesia: Sejarah, Pemikiran, Hukum dan Perkembangannya, Bandung: Yayasan Piara.

Qahaf, Mundzir, 2007, Manajemen Wakaf Produktif, terj. Muhyiddin, Jakarta Timur: Khalifa.

al-Qalyubi, Syihabuddin Ahmad, tt, Hāsyiyah al Qalyûbiy 'alā al Syarh al Muhallā li al Minhāj, Beirut: Daru Ihya' al Kutub al "arabiyyah

Rahardjo, Satjipto, 1985, Beberapa Pemikiran tentang Ancangan Antar Disiplin dalam Pembinaan Hukum Nasional, Bandung, Sinar Baru.

al- Ramli, 1984, Nihāyah al-Muhtāj ilā Syarh al-Minhāj, Juz V, Bairut: Dar al Fikr.

Ranuhandoko, I.P.M., 2003, Terminologi Hukum, Jakarta: Sinar Grafika.

Rasyid, Roihan A., 1991, Hukum Acara Peradilan Agama, Jakarta: Rajawali. 
Redaksi Sinar Grafika, 2008, Amandemen Undang-Undang Peradilan Agama (UU RI No. 3 Tahun 2006), Jakarta: Sinar Grafika.

Ricklefs, M.C., 1994, Sejarah Indonesia Modern, Yogyakarta: Gajah Mada University Press.

Rofiq, Ahmad, 2000, "Kritik Metodologi Formulasi Fiqh Indonesia" dalam Epistemologi Syara' Mencari Format Baru Fiqh Indonesia, Yogyakarta: Pustaka Pelajar.

, 2000, “Tanah Wakaf Menurut Syar'i” dalam Melacak Banda Masjid yang Hilang, Semarang: Aneka Ilmu.

Sabiq, Sayyid, 1971, Fiqh as Sunnah, Libanon: Dar al 'Arabi.

Sabri, Zulfan (Ed.), 1990, "Peradilan Agama dalam Wadah Negara Pancasila: Dialog

Tentang Rancangan Undang-Undang Peradilan Agama,” Jakarta: Pustaka Antara.

Sanit, Arbi, 1998, Reformasi Politik, Yogyakarta: Pustaka Pelajar.

Santoso, Urip, 2012, Hukum Agraria; Kajian Komprehensif, Jakarta: Prenada Media.

Sastroatmojo, Arso dan Wasit Aulawi, 1975, Hukum Perkawinan di Indonesia, Jakarta: Bulan Bintang.

ash-Shan'ani, Ahmad, 1366 H, Al Tāj Al Mazhab lī Ahkām Al Mazhab, Mesir: Isa Al Babi Al Halabi.

ash-Shiddieqy, Muhammad Hasbi, 1999, Pengantar Ilmu Fiqh, Semarang: Pustaka Rizki Putra.

Shihab, Alwi, 2001, Islam Sufistik: Islam Pertama dan Pengaruhnya hingga Kini di Indonesia, Bandung: Mizan.

Siroj, Malthuf, A., 2012, Pembaruan Hukum Islam di Indonesia, Yogyakarta: Pustaka Ilmu.

Sitegat, Amir Effendi, 1983, Patah Tumbuh Hilang Berganti, Jakarta: Karya Unipress.

Sudarsono, Juwono, "Integrasi, Demokrasi dan Pembaruan Politik," dalam Kompas 2 Desember 1987.

Suhadi, Imam, 1985, Hukum Wakaf di Indonesia, Yogyakarta: Dua Dimensi.

Sumardjono, Maria S.W., "Implikasi Yuridis Kebijaksanaan Penguasaan dan Penggunaan Tanah di Pedesaan Menyongsong Era Industrialisasi" makalah pada Seminar Nasional Tri Dasa Warsa UUPA FH-UGM dan BPN, Yogyakarta, 24 Oktober 1990.

Jakarta: Penerbit Kompas.

Suminto, Aqib, 1985, Politik Islam Hindia Belanda, Jakarta: LP3ES.

Suryanegara, Ahmad Mansyur, 1998, Menemukan Sejarah: Wacana Pergerakan Islam di Indonesia, Bandung: Mizan.

Suseno, Frans Magnis, tt, "Seputar Rencana Undang-Undang Peradilan Agama," dalam Soal Peradilan Agama Prof. Dr. HM. Rasjidi Menjawab Frans Magnis Suseno, Jakarta: Dewan Dakwah Islamiyah Indonesia Pusat.

Sutiknjo, Iman, 1990, Politik Agraria Nasional, Yogyakarta: Gadjah Mada University Press.

Syah, Ismail Muhammad, 1992, Filsafat Hukum Islam, Jakarta: Bumi Aksara.

asy- Syaibani, Abu Bakar, 1322 H/ 1922 M, Ahkām al Auqāf, Mesir: Diwan Umum al Auqaf.

asy- Syarbini, tt, Mughnī al Muhtāj, Juz II, Kairo: Mustafa al Kalabi.

Taqiyuddin, Al-Imam, tt, Kifāyat al Akhyār, Juz I, Pekalongan: Raja Murah.

Thalib, Sajuti, 1985, Recepti a Contrario: Hubungan Hukum Adat dan Hukum Islam, Jakarta: Bina Aksara. 
ath- Tharablisi, Burhanuddin Ibrahim, 1292 H, Al Is'āf fì Ahkām al Auqāaf, Mesir: Al Kubra.

Wahid, Marzuki dan Rumadi, 2001, Fiqh Madzhab Negara: Kritik atas Hukum Islam di Indonesia, Yogyakarta: LKiS.

Wahyudi, 2004, Peradilan Agama di Indonesia, Yogyakarta: Pustaka Pelajar.

Wertheim, W.F., 1956, Indonesian Society in Transition, Bandung: Sumur.

Widiana, Wahyu, 2003, Aktualisasi Kompilasi Hukum Islam di Peradilan Agama dan Upaya Menjadikannya Sebagai Undang-undang, Makalah tidak Dipiblikasikan.

Wignjosubroto, Soetandyo, 1995, Dari Hukum Kolonial ke Hukum Nasional: Dinamika Sosial-Politik dalam Perkembangan Hukum di Indonesia.

Wiradi, Gunawan, 2000, Reforma Agraria, Yogyakarta: Pustaka Pelajar.

Yasir, "Pembaruan Regulasi Hukum Perwakafan," dalam Jurnal Aplikasi Manajemen (ISSN 1693-5241), Vol 7 No. 1 Pebruari 2009.

Yahya, Abu Zakaria al-Maliki, Risālat Khithāb fì Hukmi Bai' al Ahbās, Mesir: Darul Kutub.

Yusuf, Agus Fathuddin, 2000, Melacak Banda Masjid yang Hilang, Semarang: Aneka Ilmu.

Zakaria, Abu Yahya, tt, Fath al Wahhāb, Juz I, Semarang: Usaha Keluarga.

az- Zuhaili, Wahbah, tt, Al Fiqhu al Islāmi wa Adillatuhu, Damaskus: Dar al Fikr al Mu'ashir. 